\title{
NATO in Afghanistan: A Test of the Transatlantic Alliance
}

\section{Paul Gallis *}

\section{Introduction}

NATO's mission in Afghanistan is seen as a test of the Allies' military capabilities and their political will to undertake a complex mission. Since 11 September 2001, the member states have sought to create a "new" NATO, able to go beyond the European theater and combat new threats such as terrorism and the proliferation of weapons of mass destruction (WMD). NATO is seeking to be "global" in its geographic reach and in the development of non-member partner states that can assist in achieving specific missions. This change in overall mission reflects a NATO consensus that the principal dangers to allied security lie distant from the treaty area and require new political tools and military capabilities to combat them.

Two military operations in Afghanistan seek to stabilize the country. Operation Enduring Freedom (OEF) is a combat operation led by the United States against $\mathrm{Al}$ Qaeda remnants, primarily in the eastern and southern parts of the country along the Pakistan border. OEF is not a NATO operation, although many coalition partners are NATO members. Approximately 11,000 troops are involved in OEF, including 10,000 U.S. forces. ${ }^{1}$ The second operation is the International Security Assistance Force (ISAF), established by the international community in 2002 to stabilize the country. NATO assumed control of ISAF the following year. By July 2007, ISAF had an estimated 35,000 troops from thirty-seven countries, with NATO members providing the core of the force. The United States has 15,000 to 17,000 troops deployed in ISAF.

NATO's effort in Afghanistan is the alliance's first "out-of-area” mission beyond Europe. The purpose of the mission is the stabilization and reconstruction of Afghanistan. Although NATO has undertaken stabilization and reconstruction missions before-for example, in Kosovo - the scope of the undertaking in Afghanistan is considerably more difficult. Taliban and Al Qaeda remnants are resisting the operation, Afghanistan has never had a well-functioning central government, and Afghanistan's distance from Europe and its terrain present daunting obstacles. Reconstruction must therefore take place while combat operations, albeit often low-level, continue. And although the allied forces agree upon a general political objective, some have differing interpretations of how to achieve it.

The mission in Afghanistan is likely to be important for NATO's future, and for U.S. leadership of the Alliance. The European allies insisted that a UN resolution govern NATO's mission, in order to give legitimacy to the insertion of NATO troops in

Paul Gallis is a Specialist in European Affairs in the Foreign Affairs, Defense, and Trade Division of the Congressional Research Service. This essay was prepared as a CRS Report for Congress, Code RL33627.

1 For details of the military operations in Afghanistan, see Andrew Feickert, U.S. and Coalition Military Operations in Afghanistan, CRS Report RL33503 (Washington, D.C.: Congressional Research Service, updated 11 December 2006). 
Afghanistan. This important political requirement was achieved. In the past several years, NATO governments have also repeatedly pledged to develop capabilities that will render their forces more expeditionary and "deployable" in nature. The mission in Afghanistan provides a hard test of these capabilities. Several key NATO members, above all the United States, have insisted that the Allies must generate the political will to counter the greatest threats to their security. Again, Afghanistan provides a test of will against the concrete danger of international terrorism.

NATO's mission in Afghanistan also represents a test of U.S. leadership of the Alliance. Some member states question whether the United States will distance itself from inhumane practices reportedly used in U.S. military-run prisons (such as at Guantanamo) and whether the U.S. commitment to the interests of the Allies preserves the mutual sense of obligation that at one time more clearly characterized the Alliance. The member states also believe that the United States, as a global power, must provide leadership and resources to counter the destabilizing influences upon Afghanistan of two neighboring states, Iran and Pakistan.

Afghanistan presents a growing challenge to NATO. Over the past two years, Taliban attacks have increased in scope and number, and Taliban fighters are adopting some of the tactics, such as roadside bombs, used by insurgents in Iraq. The Karzai government in Afghanistan is coming under international criticism, and its public support has diminished due to corruption and an inability to improve living conditions. Some regional warlords continue to exert influence, and the narcotics industry remains an entrenched threat to the country's political health. ${ }^{2}$ The Allies are not in full agreement on how to counter these problems, but officials in allied nations say that they need a strong and reliable Afghan government to provide reasonable services and competent leadership to the population if NATO is to succeed.

This essay follows the path of the evolution of NATO's mission in Afghanistan. The first section covers the initial two stages of ISAF's mission, and analyzes key issues in the mission: use of Provincial Reconstruction Teams to stabilize and rebuild the country; overcoming caveats placed by individual allies on the use of their forces; and managing the counter-narcotics effort. The next section examines the debate over how to develop a refined mission statement and a new organizational structure for Stage Three by analyzing issues that are both political and military in nature, such as securing more troops, the treatment of prisoners, and organization of command; it covers roughly the period December 2005-Fall 2006. By Spring 2006, the allies began to realize that Stage Three would require a greater combat capability than was originally believed, and the mission began to change. This adjustment in mission is the subject of the next section of the essay, which discusses Stage Three and overall ISAF operations beginning in July 2006 through the perspective of several key participant nations. The next section discusses Stage Four, in which ISAF has assumed control of the entire country. The final section assesses ISAF's progress to date.

2 For an overview and analysis of key issues in Afghanistan, see Kenneth Katzman, Afghanistan: Post-War Governance, Security, and U.S. Policy, CRS Report RL30588 (Washington, D.C.: Congressional Research Service, updated 10 September 2007). 


\section{Evolution of NATO in Afghanistan: Stages One and Two}

\section{Purpose of the Mission}

The United Nations, at the request of Afghan President Hamid Karzai, asked for NATO's military presence in Afghanistan, supported by Security Council resolutions. The Security Council passed the currently governing resolution, S/RES 1623, unanimously on 13 September 2005, to be in force until mid-October 2006, when it was renewed. The resolution called upon NATO to disarm militias, reform the justice system, train a national police force and army, provide security for elections, and combat the narcotics industry. ${ }^{3}$ The resolution did not provide details of how NATO should accomplish these tasks; rather, the Allies among themselves, in consultation with the Afghan government, refined the resolution's provisions into active policy.

NATO involvement began in Afghanistan under a UN mandate in August 2003. Some non-NATO states, such as Australia and New Zealand, contributed resources to the effort. Over time, the Alliance laid out four stages to bring most of Afghanistan under NATO control. NATO leaders have faced considerable difficulty in persuading allied states to contribute forces to ISAF.

In Stage One, consisting of the period from August 2003 through 2004, NATO moved into the northern part of the country, predominantly relying on French and German forces. Stage Two began in May 2005, when NATO moved into western Afghanistan; Italian and Spanish forces are the core of the NATO force there. These sections of the country are relatively stable. Stage Three began in July 2006 when ISAF moved into southern Afghanistan, where U.S., British, Canadian, and Dutch forces predominate. Stage Four began in October 2006, when ISAF took control of the entire country. The U.S.-led OEF simultaneously continues its combat operations in border regions still under threat.

\section{National Caveats}

Some member states often commit forces to a NATO operation, and then impose restrictions- "national caveats"—on the tasks those forces may undertake. These restrictions, for example, may prohibit forces from engaging in combat operations or from patrolling at night due to a lack of night-vision equipment. ${ }^{4}$ In addition to these caveats, some governments do not permit their forces to be transferred to other parts of Afghanistan. Caveats pose difficult problems for force commanders, who seek maximum flexibility in utilizing the troops under their command. NATO must accept troops from individual governments and shape the mission to fit the capabilities of and caveats on those troops. NATO commanders have sought to minimize the number of caveats on forces dedicated to ISAF, an effort that has met with mixed success.

At the Alliance's summit in Riga, Latvia, in late November 2006, NATO leaders sought to reduce the caveats placed on forces deployed in Afghanistan. The United

\footnotetext{
3 UNSC 8495, 13 September 2005.

4 Interviews of NATO officials, February 2006.
} 


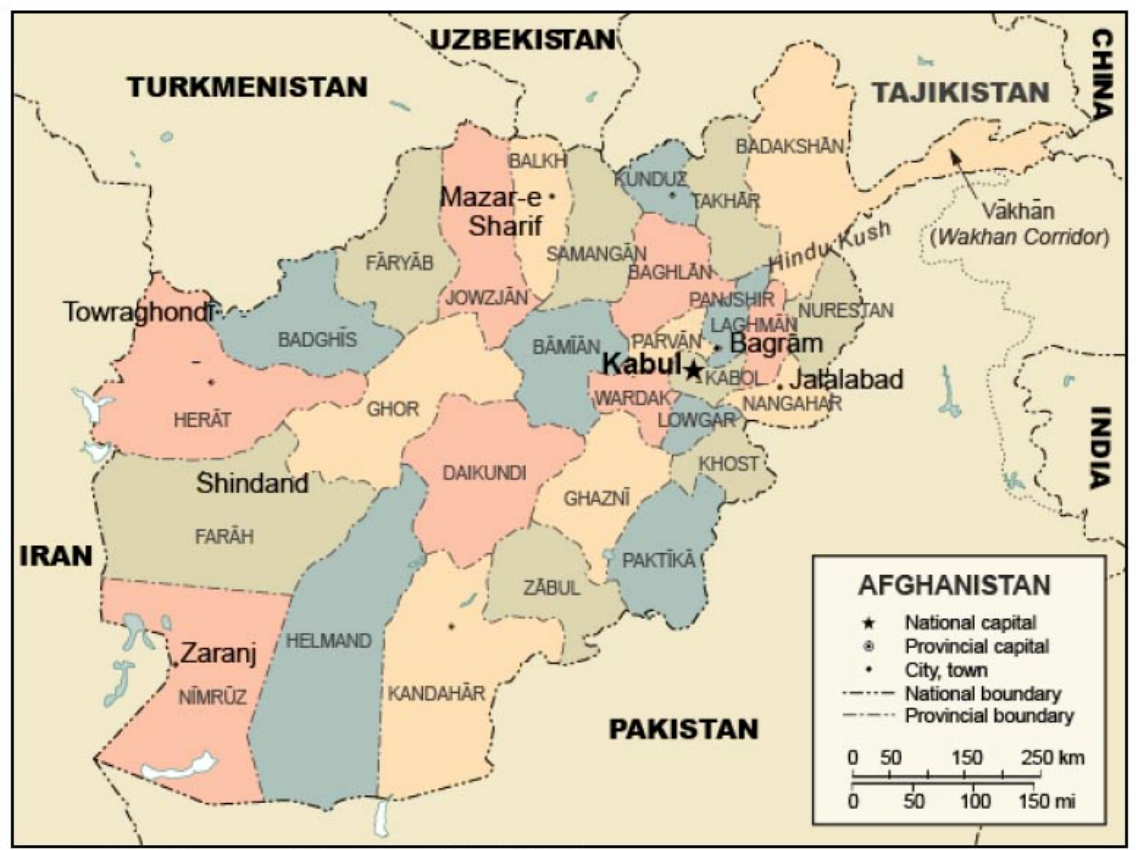

Source: Map Resources. Adapted by CRS. (8/23/06)

Figure 1. Map of Afghanistan

States, Canada, Britain, and the Netherlands have forces deployed in southern and eastern Afghanistan-highly unsettled areas-and have appealed to other governments to release combat forces to assist them in moments of danger. The French government reduced its caveats and agreed to allow its forces in Kabul and elsewhere to come to the assistance of other NATO forces in an emergency. Turkey, in contrast, refused to change its proscription against its forces' use in combat. The Italian and Spanish governments said that their force commanders in the field could make the decision to send forces to assist in an urgent situation. It remains unclear whether and when these commanders would have to request permission from their capitals to do so, a complicating factor that could delay a decision. Some Allies have singled out Germany for special criticism, given that Germany has a large contingent of 2,800 troops in a relatively quiet area of northern Afghanistan. At Riga, the Germans left the situation murky; it is unclear whether Germany will send combat forces to assist in an emergency. ${ }^{5}$

The issue moved into the public arena in November 2006 in meetings of the NATO Parliamentary Assembly in Quebec City. One British Member of Parliament asked his German colleagues, "If the situation were reversed and German soldiers were in immi-

5 Interviews at the NATO Defense College, Rome, December 2006, and Washington, D.C., April-May 2007. 
nent danger, how would you feel if the British commander responded to a German request for urgent assistance with the answer, 'Sorry, we can't come across the line to help you.'?”6

\section{Provincial Reconstruction Teams}

NATO officials describe Provincial Reconstruction Teams (PRTs) as the "leading edge” of the Allies' effort to stabilize Afghanistan. Some NATO member governments believe that poor governance, rather than an insurgency, is the principal problem impeding stabilization of the country. NATO's assistance to the Afghan government in controlling the narcotics trade, disarming militias, reducing corruption, and building an economic infrastructure is the essence of the effort to bring stability to the country. The purpose of the PRTs is to extend the authority of the central government into the countryside, provide security, and undertake projects (such as infrastructure development) to boost the Afghan economy. U.S. PRTs are composed of soldiers, civil affairs officers, representatives of the U.S. and other government agencies focused on reconstruction, and Afghan government personnel. NATO now controls 24 PRTs. U.S. officials say that they would like to see more NATO and OEF PRTs created in 2007.

There is no established model for PRTs, and they receive mixed reviews. By most accounts, those serving in U.S. PRTs make an effort to move about surrounding territory, engage the local governments and citizens, and demonstrate that the U.S. presence is bringing tangible results. The United States government controls the funds for its PRTs, in part to ensure that the money does not disappear through the hands of corrupt officials in the provinces or in Kabul, and that it goes directly to designated projects. U.S. PRTs also have the military capacity to respond to any situation in which their personnel are endangered. While not overtly offensive military instruments, U.S. PRTs are directed to provide security and respond aggressively to any threat. ${ }^{8}$

By most accounts, ISAF PRTs differ considerably from those of the United States. While their mission is the same, their resources and activities are not. ISAF PRTs generally have fewer personnel. Some U.S. officials believe that most European-led PRTs are too hesitant in their engagement of the Afghan population. Some European-led PRTs are minimally funded, or provide little supervision of how their funds are managed and dispensed. ${ }^{9}$ Individual European government perspectives on PRTs will be more fully discussed in another section of the essay that will illustrate the range of allied thinking on the principal issues confronting ISAF.

Author's notes, Debate in the NPA Political Committee, 12 December 2006.

Statement of Nancy Powell, Acting Assistant Secretary for International Narcotics and Law Enforcement Activities, U.S. State Department, to the House Armed Services Committee hearing, 22 June 2005; interviews with European officials, November 2005-July 2006.

8 Provincial Reconstruction Teams in Afghanistan-An Interagency Assessment (Washington, D.C.: Department of Defense, 26 April 2006); Interviews of U.S. officials, 2006-07.

9 Interviews of U.S. officials, 2005-07. 


\section{Counter-Narcotics}

The Allies are struggling to combat Afghanistan's cultivation of opium poppies. Afghanistan supplied 92 percent of the world's opium as of 2006. The crop is a major factor in the economic life and stability of the country, and by one estimate accounts for 40 percent of Afghanistan's gross domestic product (GDP). ${ }^{10}$ Opium poppy farmers are heavily concentrated in the southern part of the country.

The repercussions of Afghanistan's poppy crop for the future of the country and for ISAF operations are extensive and complex. The Afghan government lacks the law enforcement apparatus, including a well-functioning judicial system, to successfully combat the narcotics trade. Narcotics traffickers can exploit the country's primitive transportation network, as an extensive road system is not needed to move opium to market; a small load of opium can yield a high financial return.

The opium trade has a corrosive effect on Afghan society. Former CIA Director John Negroponte told Congress in January 2007 that "the drug trade contributes to endemic corruption at all levels of government and undercuts public confidence. A dangerous nexus exists between drugs and insurgents and warlords who derive funds from cultivation and trafficking." At the same time, farmers in some parts of the country view the poppy as their only source of income. Eradication of the industry without a substitute source of income would throw these farmers into destitution, and they violently resist any effort to destroy their crops. Some Alliance officials believe that destruction of the poppy crop at this juncture in NATO operations could fuel an insurgency. The Allies have decided against the destruction of poppy fields, but they provide training, intelligence, and logistics to Afghan army units and police who destroy opium labs. ${ }^{11}$ One former regional commander believes that the Afghan government's destruction of poppy fields is too random to be effective, and that the government does not take decisive action to end warlord involvement in the narcotics trade. ${ }^{12}$

Under these circumstances, ISAF and the Karzai government are working on a long-term solution to the problem. NATO is assisting in the construction of an Afghan law-enforcement infrastructure intended to dismantle the opium industry and prosecute drug traffickers. To this end, ISAF is training a special narcotics police force and developing a professional judiciary, heretofore absent in Afghanistan. Each is a project that may require years to accomplish. Some Western officials in Afghanistan note that

10 See Christopher Blanchard, Afghanistan: Narcotics and U.S. Policy, CRS Report RL32686 (Washington, D.C.: Congressional Research Service, updated 14 September 2007); Pankaj Mishra, “The Real Afghanistan,” New York Review of Books (10 March 2005): 44-48; “L’Afghanistan a fourni 87 \% de l' opium mondial en 2004,” Le Monde (1 July 2005), 6; “Global Opium Down 22 \%,” Associated Press, 26 June 2006; House Armed Services Committee, hearing on "Security and Stability in Afghanistan," 28 June 2006.

11 Testimony of Director Negroponte, “Annual Threat Assessment,” Senate Select Committee on Intelligence, 11 January 2007; House International Relations Committee, hearing on “U.S. Counternarcotics Policy in Afghanistan,” 17 March 2005; Mishra, “The Real Afghanistan," 46.

12 Interview, June 2007. 
the country has very few well-educated individuals able to serve in the judiciary and in other professions. In the view of most observers, the entire judicial system is greatly deficient. The police remain corrupt and distrusted by the population. They lack extensive training and experience, as well as effective transport. The court system remains in its infancy, with few capable jurists and attorneys. ${ }^{13}$

Another component of the counter-narcotics effort is to persuade farmers to switch to alternative crops. Such crops cannot compete with poppies; income from a hectare of poppies can reach USD 4600 a year, while wheat, one of the suggested substitute crops, can bring only USD 390. Orchards might bring more money, but they require years to cultivate. A more extensive market infrastructure is necessary as well. U.S. officials believe that an extensive road-building effort is imperative to modernize the country's economy.

\section{Stage Three: Establishing Mission and Structure}

ISAF's task in Stage Three is to bring stability to the southern part of the country, where the reach of the Karzai government is limited. Initially, in late 2005, the Allies believed that Stage Three would emulate Stages One and Two by seeing a replacement of OEF forces by NATO forces in a stabilizing environment. The Allies nonetheless knew that there would be several significant new challenges in Stage Three. The Taliban originated in the south, in Kandahar Province, and they retain their most active network there. Poppy farming is widespread in the south, particularly in Helmand Province, where British troops operate, and in Uruzgan Province, where Dutch troops predominate.

Stage Three came into force on 31 July 2006, after having been postponed several times due to violence and an effort to secure pledges of troops from allied governments. Elements of ISAF had been present in the region for several months, preparing for their mission. Several non-NATO states, such as Australia and New Zealand, are contributing modest amounts of troops, money, and expertise to ISAF, a sign of the importance of the mission in South Asia and to the Allies' effort to build a "global NATO” of members and partner states.

The Allies confronted four issues in attempting to develop a coherent force for Stage Three: writing a mission statement; raising troops to accomplish that mission; agreeing upon treatment of prisoners; and creating a command structure.

\section{Mission Statement}

From fall 2005 through early 2006 the Bush Administration wished to merge the functions and command of ISAF and OEF. Then-Defense Secretary Donald Rumsfeld asked the Allies to assume counter-insurgency and anti-terror responsibilities in the southern and eastern parts of Afghanistan. Some nations balked, contending that such

13 Interviews with European Union officials, 2006-07; presentation of former Afghan Finance Minister Ashraf Ghani, Brookings Institution, 30 April 2007; and "McCaffrey Sees 2007 as a Crucial Year,” Washington Post (10 April 2007), A15. 
combat operations were OEF's task, that the UN resolution governing ISAF called for a stabilization operation only, and that, in some cases, they did not have forces available for the counter-insurgency and counter-terror tasks. ${ }^{14}$

In December 2005 the Allies announced a mission statement for ISAF's Stage Three in the form of a communiqué. They pledged to work to extend the authority of the Afghan government, primarily through development of PRTs. They also committed themselves to training the Afghan army and police, an effort in state-building meant to provide the Kabul government with reliable security forces, a formidable task because such forces were barely in existence. They further committed themselves to "supporting Afghan government counter-narcotics efforts." 15 They also agreed upon guidelines for dealing with prisoners.

The mission statement reflected European and Canadian views that Stage Three operations should concentrate on reconstruction and stabilization, with only minimal initial concern given to military threats. The Taliban were relatively quiet when the Allies wrote their communiqué, perhaps due to the winter weather in Afghanistan, perhaps because the Taliban were organizing and seeking to gather their strength. In April 2006, Britain's then-Defense Secretary said that he hoped that his country's forces could deploy "without firing a shot." ${ }^{16}$ Peter Struck, Defense Minister under the previous German government, said in September 2005 that "NATO is not equipped for counter-terrorism operations. That is not what it is supposed to do." ${ }^{\text {17 }}$ The Dutch Parliament held a contentious debate in February 2006 over whether to send forces to ISAF. Some government and opposition members of Parliament opposed sending Dutch forces for a combat operation; their view was clear that Dutch forces were intended primarily to support a stabilization mission. ${ }^{18}$

By the spring of 2006, events on the ground in Afghanistan imposed new exigencies on ISAF's mission. An attack on the Norwegian-Finnish PRT in normally tranquil Meymaneh, in western Afghanistan, in February 2006 had given an indication of an emerging problem: the need for a rapid military response capability for rescue operations. When the PRT was attacked, no NATO combat forces were in the region to protect the ISAF personnel. Other NATO forces that were nearby had caveats prohibiting their use in combat operations. Eventually, a British plane and forces were contacted, and they repelled the attack on the PRT. Before and after the attack on the PRT, then NATO SACEUR General James Jones called upon the NATO governments to pledge forces to ISAF that would be capable of combat operations. He waged a con-

14 “Europeans Balking at New Afghan Role,” New York Times (14 September 2005), 1; interviews of European officials, September 2005-February 2006.

15 “Final Communiqué,” North Atlantic Council, NATO, Brussels, 8 December 2005.

16 “UK Warned of More Afghanistan Deaths,” Financial Times (3 July 2006), 3.

17 “Europeans Balking at New Afghan Role.” Struck's view seems to be contradicted by the 1999 NATO Strategic Concept, the Alliance's guiding political document, which clearly states that counter-terrorism is one of NATO's new post-Cold War tasks.

18 "Peacekeeping in Afghanistan Is Modern Crisis Management," European Affairs (Spring/ Summer 2006): 3-4. 
stant campaign to cajole allied governments not to place caveats on their forces that ruled out combat operations. ${ }^{19}$

NATO governments ultimately agreed to adjust how ISAF would fulfill Stage Three. They wrote more "robust" rules of engagement, which have not been made fully public. By May 2006, British General David Richards, then the ISAF commander, was describing Stage Three as a "combat operation." He added that caveats affecting Stage Three forces had been "reduced." He dismissed the tendency of some NATO governments to draw a line between OEF's counter-terror operations and the supposedly lowlevel counter-insurgency responsibilities that had crept into Stage Three responsibilities. He told visiting members of a NATO parliamentary delegation that counter-terror and counter-insurgency operations in Afghanistan were not always distinguishable from one another. ${ }^{20}$ When OEF turned southern Afghanistan over to ISAF on 31 July, some OEF forces remained in the region to continue combat operations targeted against terrorist elements.

\section{Difficulties in Raising Troops}

The debate over the scope of the mission affected the effort to raise forces for Stage Three. Since 2005, NATO officials have experienced difficulty persuading member governments to supply forces. According to NATO officials, the attack on the Norwegian-Finnish PRT awakened some governments to the continuing threat posed by instability and the insurgency. ${ }^{21}$ Rapid-response forces suddenly became available. Britain, Canada, and the Netherlands pledged forces for Stage Three.

Britain initially promised to send 3600 troops to Helmand Province by the beginning of Stage Three operations in July 2006. London met this deadline, and in July promised another 900 troops to counter the growing Taliban insurgency and other elements opposing the Karzai government. Canada was one of the first member states to recognize the need for combat forces. By a close vote in the Canadian Parliament in May 2006, the government designated 2300 troops for Afghanistan until February 2009, most of which have been sent to Kandahar province.

The debate in the Dutch Parliament over assigning troops to ISAF was also contentious. The Dutch population initially opposed sending forces into a combat operation. Ultimately, the Netherlands designated 1,400 to 1,700 troops for duty in ISAF's Stage Three and Stage Four operations. The views of the British, Canadian, and Dutch governments will be discussed more extensively later in this report.

\section{Disagreements over Treatment of Prisoners}

There was a contentious debate among the Allies over the December 2005 final communiqué guiding NATO operations in Afghanistan. Most of the Allies were critical of

\footnotetext{
19 Comments by Gen. Jones at NATO Parliamentary Assembly meetings in Copenhagen, November 2005.

20 "Visit to Afghanistan," report by the Defense Committee of the NATO Parliamentary Assembly, 23 May 2006, 2.

21 Interviews with NATO officials, February 2006.
} 
U.S. abuse of prisoners at the Abu Ghraib prison in Iraq; they extended this criticism to the U.S. detention policy at Guantanamo Bay, where some prisoners captured in Afghanistan have been sent since 2001. These governments contended that the Bush Administration was ignoring the Geneva Convention governing treatment of prisoners taken in combat, and that the issue was a significant one among their publics and in their domestic political debates. ${ }^{22}$

These states insisted that the communiqué explicitly address the issue of treatment of prisoners. The final document contains the statement: "In addition to NATO's agreed detention policy for ISAF, which is and remains consistent with international law, we welcome initiatives by Allies to assist the Afghan authorities in the implementation of international standards for the detention of prisoners.,"23

The Allies also agreed that prisoners taken by ISAF should be turned over to the Afghan government. Some NATO governments reportedly told the Afghan government that they did not wish such prisoners to then be transferred to the United States government. The Afghan government reportedly insisted upon its sovereign right to determine the disposition of prisoners in its custody. A new problem, discussed below, has arisen over allegations that Afghan officials have tortured detainees turned over to them by ISAF forces. ${ }^{24}$

\section{Command Structure: Coordinating ISAF and OEF Operations}

NATO's discussion over the command structure for Stages Three and Four in Afghanistan reflected the U.S. desire to see the Allies more fully embrace combat tasks. Reluctance on the part of some European governments to clash with the Taliban and regional warlords was evident in these discussions.

Since at least 2004, the Bush Administration began to urge the NATO member states to assume more responsibilities in the fight against insurgents and terrorists in Afghanistan. By 2005, the Administration was urging that ISAF and OEF be merged under one command. Many Allies at first resisted the call to merge the two commands, largely because of the different nature of the two operations and differing national agendas.

Britain, Germany, and France were the principal member states opposing the U.S. proposal to merge the commands. They did so for differing reasons. Britain and Germany wished to preserve ISAF as a stabilization (instead of combat) mission. Britain, leading the ISAF anti-narcotics effort, wished to ensure that that initiative remained in the political sphere; along with other allied states, the British believe that using force against Afghan farmers to eradicate the poppy crop might result in a broadened insurgency. Germany opposed a merger of the commands because German forces in ISAF were trained only for stabilization, and not for counter-insurgency operations.

${ }^{22}$ Interviews with officials from NATO governments, December 2005-February 2006; "En Afghanistan, l'OTAN évolue de la pacification vers le contre-terrorisme," Le Monde (20-21 November 2005), 4.

23 “Final Communiqué,” North Atlantic Council Ministerial meeting, 8 December 2005.

${ }^{24}$ Interviews of officials from NATO governments, 2005-07. 
The French view was somewhat different. The French government was close to the U.S. view that some combat operations against the Taliban and other elements would be necessary. At the same time, French officials were concerned that the Bush Administration, after having a U.S. commander in place to guide all military activity in Afghanistan, might use NATO as a "toolbox" to accomplish Washington's broader objectives. Specifically, Paris was concerned that the Bush Administration would designate more U.S. units from Afghanistan to be sent to Iraq, and leave the Allies to stabilize Afghanistan. Administration officials insisted both publicly and privately that they had no intention of sharply reducing forces in Afghanistan. ${ }^{25}$ In fact, the Bush Administration increased the number of U.S. forces in Afghanistan.

In resolving the issue of command structure, the Allies sought to address practical problems for the two operations. ISAF and OEF operate in contiguous areas, but there is no clear dividing line between regions where the Taliban and Al Qaeda are active and the relatively stable regions of the country. A weakness of ISAF had been its deficient capability for rapid response rescue should soldiers and civilian personnel find themselves under fire.

The Allies agreed upon a "synergy," rather than a merger, of the two commands to solve this problem. The ISAF commander now has three deputies. One deputy leads the stabilization operations, working closely with the Afghan government to identify priorities in reconstruction and governance. The Italians, for example, are leading the effort to build and professionalize an Afghan judiciary. A second deputy commands air operations, as the hurdles for successful strategic and tactical airlift and search and rescue operations are formidable.

A third deputy directs security operations. This deputy answers to both the OEF and ISAF commanders. The purpose of the security commander's dual role is to provide coordination between the two operations. For example, if troops in one operation need air cover or an emergency response, then those resources could come from either OEF or ISAF, depending on which was nearest to the action and had available resources. This arrangement was in fact already in place with some NATO governments before Stage Three began. French air combat forces operating out of Tajikistan, for example, have been providing this function to troops in the field in both ISAF and OEF since 2005, and other allied nations' air components are now prepared to do the same. In addition, French and Dutch officials say that their air force components serve both commands by gathering and sharing military intelligence. ${ }^{26}$

\section{Stage Three Operations: Allied Viewpoints}

Once the Allies agreed on ISAF's mission for Stage Three, they began to differ on how to accomplish it. The previous section of this essay analyzed allied views in establishing the mission and structure of Stage Three. This section discusses the developing views of the Allies as Stage Three moved forward. Allied views began to change be-

25 Interviews of officials from NATO governments, December 2005-July 2006.

26 Interviews of officials from allied governments, November 2005-July 2006. 
tween the time of the December 2005 NATO communiqué describing ISAF's mission and July 2006, largely due to the surge in Taliban activity. For purposes of analysis, the range of views begins with those governments most hesitant about the use of combat forces in Afghanistan and proceeds through a list of governments that believe that a more forceful military hand will be necessary to stabilize and rebuild the country.

\section{Germany: Rebuild but Avoid Combat}

Chancellor Angela Merkel's coalition government had initially expressed a more decisive commitment to securing stability in Afghanistan than its predecessor. Germany now has 2,800 forces in ISAF trained for stability operations but not for combat in the northern part of the country. In September 2006, the German Parliament extended the commitment for German troops but did not give the government permission to send them outside the relatively secure region of northern Afghanistan. ${ }^{27}$ At NATO's Riga summit, as noted earlier, Germany left unclear whether it would send combat forces to assist other NATO forces under imminent threat. In the spring of 2007, the German government assigned six Tornado aircraft to Afghanistan for use in surveillance operations.

Under the preceding Schroeder government, Berlin was adamant that German forces would not engage in combat operations; according to NATO officials, the German caveat against combat has limited the Alliance in integrating German forces with those of other member nations. Former Defense Minister Struck had opposed merging ISAF and OEF commands because it "would make the situation for our soldiers doubly dangerous and worsen the current climate in Afghanistan."

Some officials from other allied governments and the EU have criticized the existing restrictions on German forces and the capabilities of those forces. These officials say that German troops and civilians rarely venture beyond the perimeter of their PRTs due to concern that they might arouse Afghan public criticism or come into contact with armed elements. German troops reportedly do not go on extended patrols and do not respond to local security incidents. Critics of the German approach say that it is important to engage local officials and demonstrate that NATO has an active approach to rebuilding the country and persuading the Afghan population that the Alliance is serving a constructive role. ${ }^{28}$

Some U.S. and European officials are also critical of the manner in which Germany managed its task of training the Afghan police force (ANP). The task was a daunting one, given the low pay provided to officers by the Afghan government and the modest numbers of police used to cover a broad territory. In this view, the Afghan police remain "corrupt and hollow" as a force. At the same time, former SACEUR General Jones said that, while training of the Afghan army is "one of the bright stories, one of the not-so-good stories ... is the inadequacy to bring similar progress to police reform,

27 “Germany/Afghanistan,” Atlantic News, 15 June 2006, 2; “Canadian and Dutch Publics Feeling Stretched by Expanded Military Role in Afghanistan,” World Public Opinion Organization, 2 June 2006.

28 Interviews of European and U.S. officials and observers, June-July 2006. 
which is the responsibility of Germany.” Part of the problem may lie in the lack of authority of the German government to order police to Afghanistan; unlike its military forces, German police must volunteer for such an assignment. ${ }^{29}$

The United States is now active in training the Afghan police, possibly as a result of the reported deficiencies in German training and the general obstacles faced by the police. Early evaluations of the U.S. effort have been mixed, as some observers believe that more trainers, funding, and equipment are necessary to make the police effective. In May 2007, the EU accepted a request by NATO to take the lead in training Afghanistan's police, a mission that began in June 2007. The police play a key role in Afghanistan's stabilization because they, along with the Afghan army, have primary responsibility for destroying poppy fields and opium labs. ${ }^{30}$

There will be a debate in the German Parliament in October 2007 over the renewal of German military involvement in Afghanistan. The left wing of the SPD reportedly wishes to remove at least Germany's contingent of one hundred special forces operating under U.S. command in the OEF.

\section{The Netherlands: An Increasingly Decisive Position}

Dutch forces are concentrated in the south, in Uruzgan Province, one of Afghanistan's most unstable regions and an area that has seen considerable Taliban activity since Spring 2006. The Abu Ghraib prison scandal and U.S. treatment of prisoners at Guantanamo are important issues in the Dutch debate over its troops' deployment in Afghanistan. Dutch officials say that "the rules of the road in fighting terrorism" are not clearly agreed upon within the Alliance. For this reason, Dutch officials were initially reluctant to have their forces closely associated with U.S. forces in Afghanistan. The Netherlands was the principal proponent of the section of the December 2005 NATO communiqué detailing NATO treatment of prisoners in Afghanistan. ${ }^{31}$

Initial Dutch efforts in ISAF were tentative and indecisive. However, Dutch troops have grown increasingly engaged in providing security, in tandem with an active and well-funded reconstruction effort.

Dutch officials offer a strategic approach to Afghanistan's problems. They believe that the Alliance must make a more concerted effort to engage regional actors-above all Pakistan, India, and Iran- to bring stability to the country. These officials are concerned that NATO's military operations are alienating the Afghan population. They advocate the creation of a general fund to rapidly compensate local victims of mistaken attacks by NATO forces. In addition, they advocate appointment of a Western coordinator for reconstruction of the country, as well as a common approach within NATO and the EU to the problems presented by the drug trade. In the Dutch view—one that is

${ }^{29}$ Cited in "If Called to Lebanon, NATO 'Could Go In,"” International Herald Tribune (28 July 2006), 3; interviews, fall 2006.

30 “Foreign Troops in North Afghanistan Say 'Drug Wars' the Biggest Threat,” Agence France Presse (30 August 2005); “Shake-up of Afghan Police ‘Brought Back Corruption,”, Financial Times (13 June 2006), 2.

31 Discussions with Dutch officials, September 2005-May 2006. 
echoed by Italy—NATO must emphasize reconstruction more than combat operations. $^{32}$

Others counter this argument by saying that "there can be no reconstruction without security.” The Taliban must be cleared out before reconstruction can proceed. The issue may be more complicated, however. U.S. General Karl Eikenberry, now the deputy of the NATO Military Committee, believes that many Taliban are not individuals who have hidden themselves in Pakistan or elsewhere outside Afghanistan, but are above all "the unemployed," those currently without a stake in Afghan society. In his view, to weaken the Taliban NATO should build roads and other economic infrastructure to help create an economy that can give Afghans promise of a better future. ${ }^{33}$ In a sense, his view is close to that of Dutch officials.

The Dutch government was the most publicly critical of U.S. handling of prisoners taken in the conflict against terrorism. Dutch government spokesmen and opposition leaders criticized U.S. handling of prisoners who had been sent to Guantanamo and called for treatment of detainees to meet the standards of "international law." In a memorandum of understanding with the Afghan government, the Netherlands secured a pledge that prisoners turned over to Kabul would not receive the death penalty for any crimes committed. The Dutch expressed their desire to the Afghan government that such prisoners not be turned over to the United States. ${ }^{34}$

In the Dutch view, ISAF's purpose is "to provide a secure and stable environment for reconstruction.” Former Dutch Foreign Minister Bot outlined his government's policy by saying that measures of "defense, diplomacy, and development" are key to ISAF's success. When necessary, Dutch troops will use force to subdue the Taliban to build stability so that reconstruction projects may take hold. A growing number of combat engagements, occasionally with U.S. troops, have occurred since late summer 2006, and Dutch forces have suffered casualties. ${ }^{35}$ The Netherlands endorsed the "synergy" between ISAF and OEF commands, and has made available four F-16s for missions in both ISAF and OEF. The aircraft may be used for missions from intelligence gathering to close air support. The Netherlands now has 1,500 troops in Afghanistan in restive Uruzgan Province; another 250 Dutch troops serve in Kabul and in northern Afghanistan.

The Dutch give their funding for PRT reconstruction activities directly to the Afghan central government, mainly through UN and World Bank channels. Dutch offi-

32 Remarks by Bert Koenders, Dutch Minister for Development and Cooperation, at CSIS, Washington, D.C., 16 April 2007. Koenders is the highly regarded former President of the NATO Parliamentary Assembly, and is well-versed in NATO issues. For a view advocating EU coordination of reconstruction/civilian programs in Afghanistan, see Julianne Smith, "How the EU Can Act Now to Assist Global Leadership,” CSIS Report (26 March 2007).

Remarks of Gen. Eikenberry at Brookings Institution conference on Europe, Washington, D.C., 30 April 2007.

34 "Peacekeeping in Afghanistan Is Modern Crisis Management,” 3-4.

35 Bernard Bot, "Saving Democracy in a World of Change," speech at Georgetown University, Washington, D.C., 24 October 2006; interviews, 2007. 
cials note the contrast with the U.S. approach, which is to bring in a "turnkey" operation in which U.S. officials are trained to undertake reconstruction projects, using U.S. manpower and equipment. The Dutch argue that the Karzai government itself must undertake responsibility for the planning and implementation of projects to rebuild the country. Only in this way, the Dutch believe, can the Afghans learn good governance and management of their own affairs. Some U.S. officials believe that the Dutch practice has led to the money being spent on other governmental purposes or landing in the pockets of corrupt Afghan officials. $^{36}$

The contentious debate in the Dutch Parliament in February 2006 over sending troops to Afghanistan raised issues that are still not fully resolved. Public support in the Netherlands for sending Dutch troops to Afghanistan has dropped sharply. In 2004, 66 percent of those polled supported the mission; by January 2006 that figure had halved, standing at 33 percent. The parliamentary vote in February 2006 provided a two-year commitment of 1,400 to 1,700 troops. Dutch officials say that, as of summer 2007, their troops' mission in Afghanistan is less of a public issue.

\section{The United States, Britain, and Canada: Active Engagement}

The governments of the United States, Britain, and Canada share similar views on how ISAF should fulfill its mission. They have sent combat forces to Afghanistan, maintain PRTs in the most unstable parts of the country, and have engaged the Taliban resurgence aggressively. Many of the British and Canadian forces for Stage Three began to arrive in Afghanistan in the spring of 2006, and worked under OEF command fighting the Taliban. On 31 July 2006, most of these forces were "rebadged" as NATO forces serving ISAF's Stage Three mission.

The United States has approximately 10,000 troops deployed in OEF. The U.S.-led OEF controlled southern Afghanistan until ISAF's succession there at the end of July 2006. The United States now has 15-17,000 troops in ISAF.

U.S. officials believe that ISAF must undertake tasks "from the lowest level of peacekeeping to combat operations against the Taliban and warlords.” OEF's task should be counter-terrorism against Al Qaeda. These officials concede that the line between the two operations is blurred, given that OEF has been fighting both an insurgency led by the Taliban and searching for Al Qaeda. ${ }^{37}$ Some allied governments believe that the U.S. combat effort is overly aggressive and, in some instances, has been counterproductive. President Karzai has said that U.S. air strikes have sometimes been poorly targeted and have carelessly killed civilians, which he believes may be alienating the population in some areas of the country.

The Bush Administration has a well-developed view of the role of PRTs. U.S. PRTs, as noted earlier, are a mixture of combat forces to provide security and logistical support, Agency for International Development (AID) personnel to develop reconstruction plans, and State Department officials to oversee and coordinate operations. In the U.S. view, PRTs should be initially established in remote areas where most non-

${ }^{36}$ Discussions with Dutch and U.S. officials, February-July 2006.

37 Discussions with U.S. officials, 2006-07. 
governmental organizations will not go. The PRTs undertake reconstruction projects such as road building to enhance economic development and irrigation networks to assist in agricultural development and diversification, and political tasks, ranging from gaining the confidence of local officials to "workshops" to educate officials and tribal leaders in governance and long-term reconstruction plans. U.S. officials express concern that, when U.S. PRTs are turned over to ISAF, succeeding allied governments sometimes take a more guarded approach to reconstruction and stabilization, or put less money into PRT projects. ${ }^{38}$

The British view on the role of its ISAF contingent mirrors the U.S. view of NATO's role in Afghanistan. Britain also has an OEF contingent, and its combat aircraft support both OEF and ISAF missions. Most of Britain's ISAF troops, numbering approximately 5,800 in the entire country and 4,200 in the south, are combat units. British forces in the south are largely in Helmand Province, the principal poppy-growing region in the country; Britain leads the ISAF effort in counter-narcotics. Some British officers have complained that their forces are inadequately equipped and need more reconnaissance aircraft and logistics capability. ${ }^{39}$ The new British government under Gordon Brown has reaffirmed the U.K.'s commitment to ISAF.

From its initially hesitant position on ISAF's mission in early 2006, noted above, the British government has adopted a more aggressive stance, caused by the increase in Taliban activity in southern Afghanistan. Britain has a clearly vested interest in ISAF's stabilization mission, not only out of concern that terrorist activity has emanated from South Asia but because most of the heroin found in the United Kingdom comes from Afghanistan. British PRTs reportedly reflect the view that ISAF must be more assertive in its stabilization efforts. U.S. officials believe that Britain's PRT in Helmand Province is well funded and concentrates on local governance and economic development. ${ }^{40}$

Canada's deployed troops in Afghanistan are also primarily combat forces, in both OEF and ISAF. There is a vigorous debate in Canada over the country's involvement in Afghanistan. In May 2006, by a narrow vote of 149-145, the Canadian Parliament approved Ottawa's plan to commit 2300 troops to ISAF until February 2009. Public support for the mission has fallen, however. In 2002, 66 percent of those polled supported sending Canadian forces to Afghanistan, and only 44 percent supported the twoyear extension for Canadian troops. By April 2007, support for keeping Canadian forces in Afghanistan had dropped to 52 percent. While Canadians appear to support

38 “Provincial Reconstruction Teams,” Dept. of Defense, 9-20; interviews with U.S. officials serving in PRTs, 2005-07.

39 “Malaise dans l'armée britannique sur son rôle en Afghanistan,” Le Monde (29 September 2006), 5.

40 “Provincial Reconstruction Teams,” 22; “Opium War an Absolute Disaster,” Financial Times (5 July 2006), 3. 
their country's long-standing involvement in UN peace operations, the need for combat operations in Afghanistan has eroded support for the ISAF mission. ${ }^{41}$

Canadian forces joined U.S. and British forces in OEF combat operations against the Taliban in southern Afghanistan in the summer and fall of 2006. Some of these operations, led by Canadian teams, were joined by Afghan army (ANA) elements in Kandahar Province. The Canadians eventually wish to turn over such operations to the ANA. Some of the Canadian forces assigned to OEF were transferred to ISAF's Stage Three operations on 31 July 2006, and Kandahar Province is their principal region of responsibility. Canada leads a PRT in the province.

Canada's mission in Afghanistan continues to be a major issue in Canadian affairs. In April 2007, the Canadian House of Commons narrowly defeated a bill to withdraw Canadian troops by a 150-134 margin. Increasingly, members of the Canadian Parliament and the media are calling upon other NATO governments to take Canadian forces' place in southern Afghanistan. ${ }^{42}$

\section{France: An Expanded Role for NATO}

The French government believes that ISAF must be a combat force that buttresses the efforts of the Afghan government to build legitimacy and governance. Unlike German forces, for example, many French forces are trained both for combat and stabilization. France has 1,100 troops in ISAF; they are largely deployed in a stabilization mission in Kabul and in army training missions elsewhere in the country. Paris withdrew 220 special forces troops from the OEF in early 2007. France has another 950 troops acting in the region in support of ISAF and Operation Enduring Freedom. The new French government under Nicolas Sarkozy has reaffirmed Paris's commitment to ISAF, but has said that French forces will not stay "indefinitely."

The Afghan mission has marked important changes in French NATO policy. France supported the invocation of Article V, NATO's mutual security clause, after the attacks of 11 September 2001 on the United States. Those attacks were decisive in the French government's change of position on NATO's “out-of-area” responsibilities. For many years, Paris had argued that NATO was a European security organization, and must only operate in and near Europe. After September 11, the French government embraced the emerging view that NATO must be a global security organization able to combat terrorism and WMD proliferation around the planet. French officials say that ISAF is NATO's most important mission. ${ }^{43}$

Since the late 1990s, NATO has urged member governments to construct more "deployable," expeditionary forces, and gave the notion a concrete base in the Prague Capabilities Commitment (PCC) in 2002, when member states pledged to develop ca-

41 “Canada Votes to Extend Mission in Afghanistan,” Washington Post (18 May 2006), A18; “Canadian and Dutch Publics Feeling Stretched,” op. cit.; “Troop Pullout Bill Defeated in Canada,” Washington Post (25 April 2007), A12.

42 “Troop Pullout Bill,” op. cit.

43 Interviews with French and U.S. officials; Remarks by Defense Minister Michèle AlliotMarie at the NATO Parliamentary Assembly plenary, Paris, 30 May 2006. 
pabilities such as strategic airlift, aerial refueling, and more special forces. ${ }^{44}$ Among the European allies, France has made considerable progress along this path. French aerial tankers refuel not only French aircraft in the Afghan theater, but U.S., Dutch, and Belgian aircraft as well. French Mirage jets based in Tajikistan gather intelligence over Afghanistan and provide close air support to both ISAF and OEF. These capabilities have contributed to the improving integration of NATO forces in the Afghan theater, according to U.S. officials, and to the ability of ISAF and OEF to share capabilities and command. ${ }^{45}$ U.S. officials give French forces high marks for their ability and their willingness to fight.

The French government has clearly defined its interests in Afghanistan. French officials argue that the allies must commit to a long effort to assist the Afghan government in eradicating the opium industry, in part because heroin finds its way into Western societies, in part because it provides funding for terrorist groups. Ultimately, French officials believe that the Afghan government itself must learn to govern the country, and that NATO and partner states cannot do this for Kabul. To this end, the French have a contingent in place that assists in training the Afghan army. France does not believe that PRTs can play a meaningful role in Afghanistan, and believes that the Karzai government must itself exercise the initiative and build good governance to gain the confidence of its people. France does not accept the view, held by some U.S. officials but nowhere present in NATO's ISAF mission statement, that part of NATO's brief is to build democracy in Afghanistan. In the French view, Afghanistan is a highly diverse ethnic state with no tradition of democracy; the best outcome, at least for the foreseeable future, is the construction of a more representative and tolerant society. ${ }^{46}$

France also contends that the EU and other civilian institutions, such as the UN and the World Bank, are better suited to undertake development projects than NATO. In Paris' view, NATO should concentrate on collective defense.

French officials are less likely to parse the NATO-defined difference that OEF is a counter-terror operation and ISAF is a counter-insurgency and reconstruction mission. French forces fight in both operations, and describe both operations as devoted to fighting terrorism and developing a more stable society. ${ }^{47}$

44 Carl W. Ek, NATO’s Prague Capabilities Commitment, CRS Report RS21659 (Washington, D.C.: Congressional Research Service, updated 24 January 2007).

45 Interviews with U.S. and French officials, 2005-07; "France Quietly Offers More Military Help,” Army Times (29 August 2005); “Français et Américains louent une coopération exemplaire en Afghanistan,” Le Monde (24-25 October 2004), 3.

46 Interviews with French officials, August 2005-July 2006; Remarks by Defense Minister Michèle Alliot-Marie at the NATO Parliamentary Assembly plenary, Paris, 30 May 2006. Afghanistan supplies an estimated 90 percent of the heroin that finds its way to France.

47 Remarks by Defense Minister Michèle Alliot-Marie at the NATO Parliamentary Assembly plenary, Paris, 30 May 2006. 


\section{Stage Four}

On 5 October 2006, ISAF extended its responsibilities to cover all of Afghanistan. A reduced OEF will continue its operations under U.S. leadership against terrorist elements.

In September 2006, then NATO SACEUR General Jones again called for European governments to contribute more troops. He said that 2,500 troops were necessary, of which 1,000 should serve as a mobile reserve component able to move rapidly to trouble spots around the entire country. He expressed frustration at the limitations that some NATO member states placed on their troops. "It's not enough," he said, "to simply provide forces if those forces have restrictions on them that limit them from being effective." ${ }^{48}$ He had specifically requested that Germany send some of its force in northern Afghanistan into the south to combat Taliban activity, but the German government refused this request. Poland eventually pledged to send one thousand additional troops to Afghanistan, a figure that still left ISAF short of the needed overall force contingent. ${ }^{49}$ In early 2007, the Bush Administration filled much of the shortfall by sending a rapid-response brigade of 3,500 soldiers to Afghanistan.

In Stage Four, the United States transferred 10-12,000 of its own troops to ISAF, who will serve under the NATO commander U.S. General Dan McNeil. ISAF now has approximately 35,000 troops.

\section{Congressional Action}

A bipartisan consensus continued to support the Afghan mission in the U.S. Congress. The Afghan Freedom Support Act of 2002 (P.L. 107-327), as amended, authorized U.S. aid for reconstruction, military operations, counter-narcotics efforts, election reform, and human rights assistance. A succession of appropriations bills has met or exceeded authorization targets.

\section{Assessment}

The NATO member nations have maintained a basic unity of purpose in Afghanistan. Their desire to stabilize the country to prevent the return of a terrorist state has led to an ongoing general consensus about operations there. Member states that refused to contribute troops to the U.S. effort to bring order to Iraq are present in Afghanistan. The Allies believe that there is a tangible benefit to ISAF. If ultimately successful, ISAF can help to build a state that is relatively stable, no longer a source of international terrorism, and one that works on its own to diminish a narcotics trade that is a threat to European societies.

Nevertheless, NATO faces complex issues within its own ranks and on the ground in Afghanistan that are likely to concern ISAF over the next several years. Although

48 “NATO Commander Asks Member Nations to Drop Troop Limits," Mideast Stars and Stripes (25 October 2006).

49 “Leaving NATO, Marine General Still Seeks Troops for Afghanistan,” New York Times (21

December 2006), A4. 
the Allies agree on their overall mission to stabilize the country, they often differ on the best means to reach that objective and on the amount of resources to be made available.

Although ISAF does not explicitly have a counter-terrorism mission, it is clear that the contributing governments believe that fighting the Taliban, regional warlords, and the narcotics trade can prevent the return of $\mathrm{Al}$ Qaeda or radical Islamist groups that would be inimical to Western interests.

NATO leaders have at times had difficulty in persuading Allies to contribute forces to ISAF. Of equal difficulty today is the effort to persuade governments to contribute the money necessary to rebuild Afghanistan. Some governments have pledged money but have not yet contributed it. Key allied governments say that they are committed to staying for a period of years to stabilize the country. Some EU officials believe that five years or more will be necessary to build a market economy and a culture of proficient governance. $^{50}$

Afghanistan's long history without a central government that was able to extend its reach over the country's difficult geographic and political terrain is presenting the Allies with problems rivaling the threat of the Taliban. Political differences within the Alliance over how to manage Afghanistan's future are apparent in ISAF's operations.

The Allies' description of PRTs as the "leading edge" of their stabilization effort masks a divergent reality. Some PRTs are clearly effective, building needed infrastructure and by most accounts gaining the confidence of local populations. Others, in the view of some U.S. and European officials, are no more than showcases, aimed more at demonstrating a particular nation's desire to participate in an important NATO mission than at producing concrete results for the stabilization plan. In the view of these same officials, NATO may be expecting too much from some of its new member governments, which, only recently having come out of communism, lack the experience and the funds to mount an effective reconstruction effort in a distant, impoverished country. ${ }^{51}$

The declining fortunes of the Karzai government also present a difficult obstacle. NATO is attempting both to respect the policies of a nascent representative government and to urge it forward to better governance. The Karzai government's own problems are apparent: discontented warlords, a vigorous drug trade, the Taliban, and a rudimentary economy and infrastructure. In the view of General Eikenberry, "The enemy we face is not particularly strong, but the institutions of the Afghan state remain relatively weak." ${ }^{\text {"2 }}$ There is a widespread view that President Karzai is losing the confidence of the Afghan people; he blames the slow pace of reconstruction and insufficient financial support from the international community. General Ed Butler, the former commander of British forces in Afghanistan, said in May 2006: "This year we need to be seen to be making a difference. It is a real danger that if people do not feel safer, we

50 “EU/Afghanistan: Europeans must Prepare for Losses,” Atlantic News (20 July 2006), 2.

51 Interviews with U.S. and European officials, 2006-07.

52 House Armed Services Committee, hearing on "Security and Stability in Afghanistan," 28 June 2006. 
may lose their consent.” In his view, poor governance and not the Taliban insurgency is the country's central problem, a view widely reflected by other officials from NATO governments. ${ }^{53} \mathrm{NATO}$, in this view, must prepare to deal with successive governments of unknown composition and policies should the Karzai government fail to endure.

NATO's effort to assist the Karzai government in weakening the narcotics trade demonstrates the central dilemma of ISAF's mission. The Allies must fight an insurgency tied to the opium industry with forceful means while at the same time attempting to win the confidence of the Afghan people through reconstruction of the country. In this view, "breaking down suspected insurgents' doors in the morning [makes] it difficult to build bridges in the afternoon." ${ }^{54}$ While NATO officials state publicly that allied forces are not burning poppy fields and are depending instead on the Afghan army and police to do the job, farmers are well aware that it is ISAF that supplies the intelligence, training, and logistics enabling government security forces to attack the opium industry, the lifeline of many poor Afghans. ${ }^{55}$

NATO's training of Afghan officials has made measured progress in some areas, but very little in others. Although the Karzai government has complained that NATO is not building a sufficiently large army, most Allies believe that substantial progress has been made in developing a professional and reliable force. Since the beginning of Stage Three, British and Canadian troops have reportedly given more and more responsibility to the ANA in joint operations. ${ }^{56}$

The police forces, as already noted, are clearly not a success story. EU officials say, in addition, that Italian efforts to train a competent judiciary have faltered, in part due to the small number of well-educated Afghans available for the legal profession, in part due to insufficient resources provided by Rome. ${ }^{57}$

The quality and practices of NATO's own forces have also come into question by some U.S. and European officials. It has already been noted that some of NATO's newer member states attempt to manage PRTs with troops that have not yet been trained for a stabilization mission in a dangerous environment. Some NATO forces also do not have the appropriate equipment for their tasks. They may lack night-vision equipment, or the technology necessary to detect roadside bombs. Some NATO governments send forces inappropriate for the task, forces that are heavy on support functions but light on combat capabilities. These governments tend to be reluctant to send their forces out into the field to confront the Taliban and to control warlords and their

53 “UK Troops 'Must Beat Back the Taliban this Year,'” Financial Times (23 May 2006), 7; interviews with U.S. and European officials, 2006-07.

54 “Mission Impossible? Why Stabilising Afghanistan Will Be a Stiff Test for NATO," Financial Times (31 July 2006), 9. The quotation is a paraphrase by the Financial Times of a French official who was reflecting on a similar dilemma for French forces in Algeria in the 1950s.

${ }^{55}$ Interviews with U.S. and British officials, 2005-07.

56 “Army Woefully Unready, Afghans Say,” Toronto Globe and Mail (16 November 2006), A13.

57 Interviews with U.S. and European officials, 2006-07. 
militias. The result, in this view, has been that British, Canadian, Dutch, and U.S. forces bear a disproportionate share of the most dangerous tasks. ${ }^{58}$

The United States has made an evident effort through its PRTs to engage local Afghan leaders and the general population to convince them of the worth of ISAF's mission. While some progress has clearly been made, several U.S. officials have noted that Afghanistan is a society where personal contact and developed relationships are critical in building trust and in persuading Afghans to pursue better governance. The short rotations of some allied forces impede this effort. Some allied governments, however, are now sending troops into Afghanistan for two-year rotations, which provide a better opportunity to gain the confidence of the population.

Cohesiveness of command is another lingering issue. While the Allies reached agreement on a command structure linking ISAF and OEF, some observers believe that national commands will preserve the authority to make final decisions about the use of their forces. The Dutch parliamentary debate clearly signaled this inclination.

ISAF may be having a residual, positive effect on the militaries of some NATO members, particularly new member states. U.S. military personnel say that true reform of new members' militaries can best take place in the field, under difficult conditions, and through operations with more experienced NATO militaries. By several accounts, this experience is being gained in Afghanistan. ${ }^{59}$

The Allies have arrived at a consensus that reconstruction is the key to building a viable, functioning Afghan state. Officials in allied governments repeatedly point to the need for more road building to extend the reach of the government in Kabul and to provide the infrastructure to diversify and strengthen the economy of a country lacking the capacity to develop enduring market practices. General Eikenberry, when asked by a Congressional committee what he needed to build a stable society, responded, "Would I prefer to have another infantry battalion on the ground of 600 U.S. soldiers or would I prefer to have USD 50 million for roads, I'd say ... USD 50 million for roads." ${ }^{\prime 0}$ His view has been echoed by calls from the NATO Secretary General for member states and international institutions to provide more funds for reconstruction.

\section{Prospects}

The Afghanistan mission is an important test of NATO's out-of-area capability. In a view of growing prevalence, Afghanistan exemplifies conditions in which "extreme belief systems, ... unstable and intolerant societies, strategic crime and the globalization of commodities and communications combine to create a multidimensional threat transcending geography, function, and capability." 61

The attacks of 11 September 2001 led the Bush Administration to abandon its skepticism about nation-building as a task for the United States or for NATO. Today,

58 Ibid.

59 Interviews with military officers from NATO governments, 2006-07.

${ }^{60}$ House Armed Services Committee, op. cit.

61 Julian Lindley-French, “Big World, Big Future, Big NATO,” NATO Review (Winter 2005): 5. 
the Pentagon gives great attention to training forces for nation-building; other Allies have also embraced stabilization and reconstruction as central to NATO's mission.

NATO's exit strategy from its mission in Afghanistan requires laying the economic foundations and providing the security for a fledgling government to find a stable political footing that excludes violence, reduces corruption, and creates a climate conducive to representative institutions. External factors will affect the realization of this exit strategy. Stabilization of Afghanistan is closely linked to developments in and the intentions of neighboring Iran and Pakistan, a situation that many in the Alliance believe demands a continuing U.S. presence. ${ }^{62}$ For these reasons, the Allies believe that the success of the mission will also be a test of the United States' ability and commitment to lead NATO, even if they do not always agree with every element of U.S. policy in the region.

U.S. leadership of the Alliance appears to have arrived at a key moment. The Bush Administration has been unable to persuade its NATO allies to play a major role in Iraq. Among the Allies, broader U.S. Middle East policy is widely seen as a failure. U.S. support for the development of democratic governments is a controversial policy. In Iraq and the Palestinian Authority, where democratic elections have taken place at U.S. urging, factions supported by Iran have fared well, enhancing Tehran's influence in a region where it was long kept at bay. Strong U.S. support for Israel in its conflict with Lebanon is another factor seen in Europe as serving to radicalize Arab populations against Western interests. ${ }^{63}$ In contrast, the United States and its NATO allies have greater unity of purpose in Afghanistan. The ultimate outcome of NATO's effort to stabilize Afghanistan-and U.S. leadership of that effort-may well affect the cohesiveness of the Alliance and Washington's ability to shape NATO's future.

62 Olivier Roy, “Afghanistan: La Difficile Reconstruction d’un État,” Cahiers de Chailliot (December 2004).

63 "U.S. Policy in the Middle East Unravels," Financial Times (4 August 2006), 3; "Washington, en s'alignant sur Israël, a perdu son influence dans la région,” Le Monde (20 July 2003), 3. 


\section{Bibliography}

Army Woefully Unready, Afghans Say. Toronto Globe and Mail (2006).

Blanchard, Christopher. Afghanistan: Narcotics and U.S. Policy. Washington, D.C.: Congressional Research Service, 2007.

Bot, Bernard. Saving Democracy in a World of Change. Washington, D.C: Georgetown University, 2006.

Canada Votes to Extend Mission in Afghanistan. Washington Post (2006).

Ek, Carl W.. NATO's Prague Capabilities Commitment. Washington, D.C.: Congressional Research Service, 2007.

En Afghanistan, l'OTAN évolue de la pacification vers le contre-terrorisme. $L e$ Monde(2005).

Europeans Balking at New Afghan Role. New York Times (2005).

Feickert, Andrew. U.S. and Coalition Military Operations in Afghanistan. Washington, D.C.: Congressional Research Service, 2006.

Final Communiqué. Brussels: North Atlantic Council, NATO, 2005.

Foreign Troops in North Afghanistan Say 'Drug Wars' the Biggest Threat. Agence France Presse (2005).

Français et Américains louent une coopération exemplaire en Afghanistan. Le Monde(2004).

France Quietly Offers More Military Help. Army Times (2005).

Germany/Afghanistan. Atlantic News (2006).

Global Opium Down $22 \%$. Associated Press (2006).

If Called to Lebanon, NATO 'Could Go In'. International Herald Tribune (2006).

Interviews at the NATO Defense College. Rome, 2006.

Jones, Gen.. Comments by Gen. Jones at NATO Parliamentary Assembly meetings. Copenhagen, 2005.

Katzman, Kenneth. Afghanistan: Post-War Governance, Security, and U.S. Policy. Washington, D.C.: Congressional Research Service, 2007.

L'Afghanistan a fourni $87 \%$ de l' opium mondial en 2004. Le Monde (2005).

Leaving NATO, Marine General Still Seeks Troops for Afghanistan. New York Times(2006). 


\section{THE QUARTERLY JOURNAL}

Lindley-French, Julian. "Big World, Big Future, Big NATO." NATO Review (2005): 5. Malaise dans l'armée britannique sur son rôle en Afghanistan. Le Monde (2006).

McCaffrey Sees 2007 as a Crucial Year. Washington Post (2007).

Mishra, Pankaj. "The Real Afghanistan." New York Review of Books (2005): 44-48.

Mission Impossible? Why Stabilising Afghanistan Will Be a Stiff Test for NATO. Financial Times (2006).

NATO Commander Asks Member Nations to Drop Troop Limits. Mideast Stars and Stripes (2006).

Opium War an Absolute Disaster. Financial Times (2006).

Peacekeeping in Afghanistan Is Modern Crisis Management. European Affairs (2006): 3-4.

Powell, Nancy. Statement to the House Armed Services Committee hearing., 2005.

Provincial Reconstruction Teams in Afghanistan-An Interagency Assessment. Washington, D.C.: Department of Defense, 2006.

Remarks by Bert Koenders, Dutch Minister for Development and Cooperation at CSIS. Washington, D.C.: CSIS, 2007.

Remarks by Defense Minister Michèle Alliot-Marie at the NATO Parliamentary Assembly plenary. Paris: NATO Parliamentary Assembly plenary, 2006.

Remarks of Gen. Eikenberry at Brookings Institution conference on Europe. Washington, D.C., 2007.

Roy, Olivier. "Afghanistan: La Difficile Reconstruction d'un État." Cahiers de Chailliot(2004).

Shake-up of Afghan Police 'Brought Back Corruption'. Financial Times (2006).

Smith, Julianne. How the EU Can Act Now to Assist Global Leadership. CSIS Report, 2007.

Testimony of Director Negroponte "Annual Threat Assessment”. Senate Select Committee on Intelligence, 2007.

Troop Pullout Bill Defeated in Canada. Washington Post (2007).

U.S. Policy in the Middle East Unravels. Financial Times (2006).

UK Troops 'Must Beat Back the Taliban this Year. Financial Times (2006).

UK Warned of More Afghanistan Deaths. Financial Times (2006). 
FALL 2007

Washington, en s'alignant sur Israël, a perdu son influence dans la région. Le Monde(2003). 